\title{
Molten Carbonate Fuel Cell Research at ORNL
}
J. Braunstein
H. R. Bronstein
S. Cantor
D. Heatherly
C. E. Vallet

\section{OAK RIDGE NATIONAL LABORATORY}

OPERATED BY UNION CARBIUE CORPORA IWW FOR THE ENERGY RESEARCH AND DEVELOPMENT ADMINISTTRATIONN 


\section{DISCLAIMER}

This report was prepared as an account of work sponsored by an agency of the United States Government. Neither the United States Government nor any agency Thereof, nor any of their employees, makes any warranty, express or implied, or assumes any legal liability or responsibility for the accuracy, completeness, or usefulness of any information, apparatus, product, or process disclosed, or represents that its use would not infringe privately owned rights. Reference herein to any specific commercial product, process, or service by trade name, trademark, manufacturer, or otherwise does not necessarily constitute or imply its endorsement, recommendation, or favoring by the United States Government or any agency thereof. The views and opinions of authors expressed herein do not necessarily state or reflect those of the United States Government or any agency thereof. 


\section{DISCLAIMER}

Portions of this document may be illegible in electronic image products. Images are produced from the best available original document. 


\section{Printed in the United States of America. Available from National Technical Information Service \\ U.S. Department of Commerce 5285 Port Royal Road, Springfield, Virginia 22161 \\ Price: Printed Copy $\$ 4.00 ;$ Microfiche $\$ 3.00$}

This report was prepared as an account of work sponsored by the United States Government. Neither the United States nor the Energy Research and Development Administration/United States Nuclear Regulatory Commission, nor any of their employees, nor any of their contractors, subcontractors, or their employees, makes any warranty, express or implied, or assumes any legal liability or responsibility for the accuracy, completeness or usefulness of any information, apparatus, product or process disclosed, or represents that its use would not iniringe prlvalely uwiıted i iglils. 
ORNL/TM-5886

Dist. Category UC-4

Contract No. W-7405-eng-26

CHEMISTRY DIVISION

MOLTEN CARBONATE FUEL CELL RESEARCH AT ORNL
J. Braunstein $\dagger$
H. R. Bronsteint†
S. Cantor $\dagger$
D. Heatherlyt
C. E. Vallet $\dagger$

+Part time on Fuel Cell Program.

†十Full time on Fuel Cell Program.

Date Published - May 1977

NOTICE This document contains information of a preliminary nature.

It is subject to revision or correction and therefore does not represent a final report. 


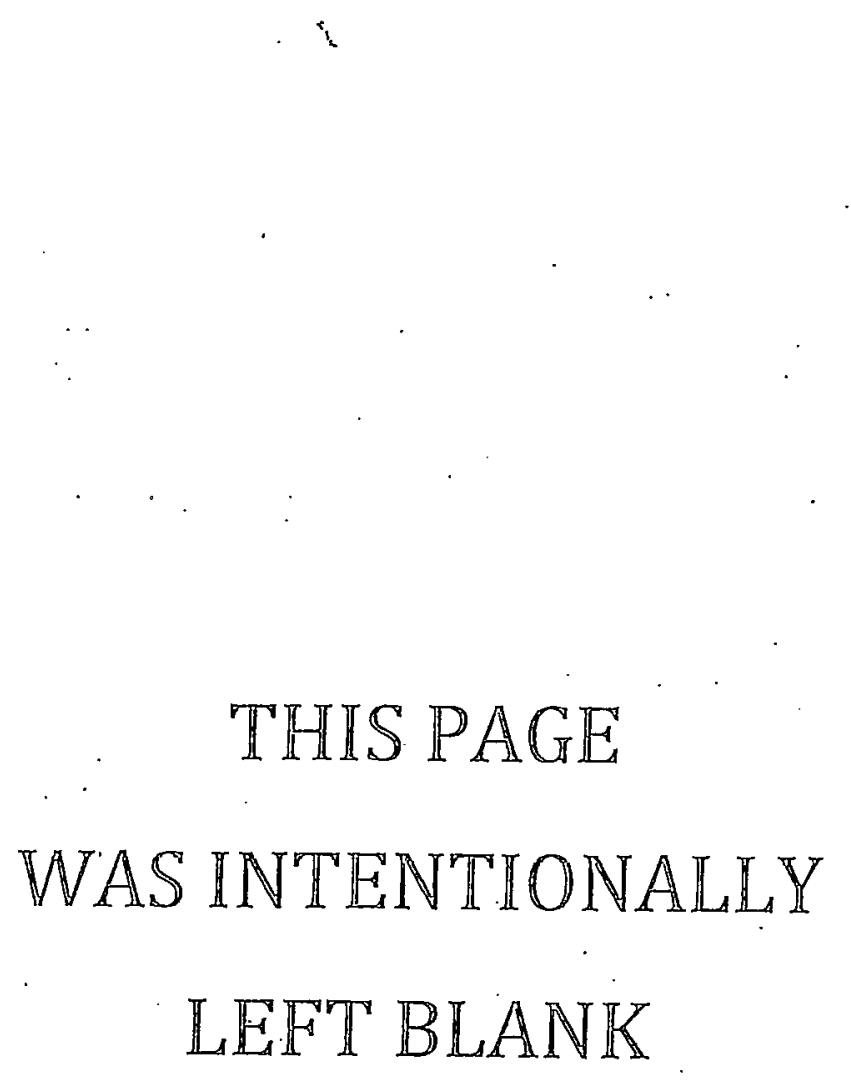




\section{CONTENTS}

\section{Title}

\section{$\underline{\text { Page }}$}

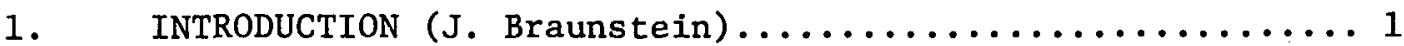

2. LITERATURE SURVEY (H. R. Bronstein)............... 2

3. MATERIALS COMPATIBILITY IN MOLTEN CARBONATES.......... 2

3.1 Sodium Beta Alumina (H. R. Bronstein) .............. 2

3.2 Boron Nitride (H. R. Bronstein and J. Braunstein)....... 3

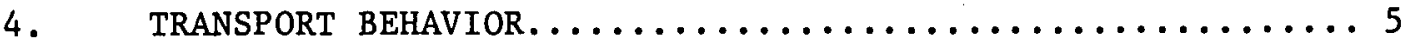

4.1 Theoretical and Model Studies

(J. Braunstein, C. E. Vallet, and D. Heatherly)........5

4.2 Electrolysis of $\mathrm{LiAlO}_{2}-(\mathrm{LI}, \mathrm{K}) \mathrm{CO}_{3}$ Tiles

(H. R. Bronstein and J. Braunstein)............... 9

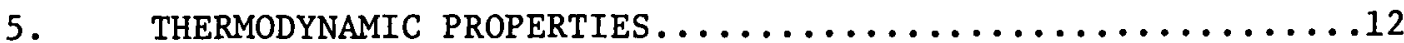

5.1 Thermochemical Properties of Alkali Carbonates

(S. Cantor and D. Heatherly) .....................

5.2 Free Energies of Molten Carbonate M1xtures.............15

5.2.1 Electrochemical Measurements (H. R. Bronstein)...........15

5.2.2 Activity Coefficients from Phase Diagrams (S. Cantor).....16

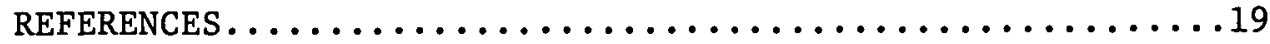


THIS PAGE

WAS INTENTIONALLY

LEFT BLANK 
This document summarizes the activities at ORNL during the period July 1976 to February 1977 on the molten carbonate fuel cell program, funded by the ERDA Division of Conservation Research and Technology. This period marks the inftiation of molten carbonate fuel cell research at ORNL, making use of the extensive background of expertise and facilities in molten salt research. The activities described in this report include a literature survey on molten carbonates, design, acquisition and Installation of apparatus for experimental studies of molten carbonates, inftial experiments on materials compatibility with molten carbonates, electrolysis experiments for the determination of transference numbers, and theoretical studies of transport behavior and the coupling of mass flows in molten carbonate mixtures.

Significant accomplishments were: the theoretical prediction of a possibly appreciable change in the alkali ion ratio at molten carbonate fuel cell electrodes, operated at high current densities, as a result of mobility differences of the alkali ions; design, construction and assembly of an electrolysis cell, and initiation of measurements of composition profiles in mixed alkali carbonate electrolytes; Initiation of differential scanning calorimetry of pure alkali carbonates for quantitative measurement of transition enthalpies, eventually leading to new, more reliable, values of the enthalpies and free energies of formation of the pure and mixed carbonates. 


\section{INTRODUCTION (J. Braunstein)}

The projected growth of U. S. energy demand, the decreasing supplies and increasing costs of petroleum and natural gas, and the adverse environmental effects of increased combustion of hydrocarbon and carbonaceous fuels combine to emphasize the need for more efficient utilization of fuels in the generation of electricity ${ }^{1}$. Direct electrochemical utilization of fuels by means of fuel cells, especially at elevated temperatures, offers one means of electrical energy generation that is potentially more efficient, than combustion of the fuels. One of the promising candidates is the molten carbonate fuel cell with gaseous mixtures containing hydrogen and carbon monoxide; derived from hydrocarbon or carbonaceous fuels and water, as the active components of the fue ${ }^{2}$. The development of fuel cells of long life and high performance characterlstics requires both a detailed knowledge of physicochemical properties of specified systems and a general understanding of the phenomena occurring in the molten salt electrolyte, at the electrodes, and in the auxiliary materials. Such understanding must be of sufficient depth to enable prediction of the effects of changes of design parameters such as electrolyte composition, fuel and oxidant gas composition, and supporting matrix on the life and performance characteristics of the fuel cells.

The program in the Chemistry Division of ORNL provides basic supportive research to the molten carbonate fuel cell program in the areas of experimental measurements and theoretical interpretation of the physicochemical behavior of molten carbonate elecyrolytes and their interactions with electrodes, gases and containment materials. Electrochemical and thermochemical methods are employed to determine properties such as electrical conductance, transference numbers, and other transport and thermodynamic properties relevant to melt stability and performance as a function of melt composition and gas composition. The experimental results and theoretical interpretation will be made available for the optimization of electrolyte composition and the provision of quantitative criteria needed in the development and demonstration of high-performance 
high temperature fuel cells. The program at ORNL was initiated as a 1-1/2 man effort drawn from a hrnad background of cxpertisc and facilities for experimental and theoretical molten salt and electrochemical research.

\section{LITERATURE SURVEY (H, R. Bronstein)}

One of the initial efforts of ORNL in the Molten Carbonate Fuel Cell Program was to provide input to a comprehensive survey of the recent literature on molten alkali carbnnates covering not only their physical properties but all aspects relevant to fuel cell operation. The aim of the survey was to compile a critically evaluated data base and to identify information gaps and discrepancies for. which reevaluation or new measurements are needed. Since much of the literature through 1970 has been summarized in reviews published up to that date, our search began with the years 1971 to the present. Using Chemical Abstracts, and the information retrieval services of S.D.C.'s "ORBIT" (International Search Service), Lockheed's "Dialog" and ERDA's "RECON", we have compiled a list of some 80 new references pertaining to alkali carbonate melts and carbonate fuel cells. These references have heen incorporated in a rcvicw published as a quarterly status report of the Institute of Gas Technology ${ }^{2}$.

\section{MATERIALS COMPATIBILITY IN MOLTEN CARBONATES}

\subsection{Sodium Beta Alumina (H. R. Bronstein)}

In order to determine thermodynamic properties of mo1.ten salt mixtures relevant to melt stability, vaporization equilibria and transport behavior, emf measurements of formation cells such as $\mathrm{A} / \mathrm{AX} / \mathrm{X}$ are desirable $\mathrm{C}^{3}$. However, in the case of the alkali carbonates, reaction would occur with the pure alkali metals. Two alternatives are the use of alloys of low activity and the use of selective ion conductive membranes. Sodium beta alumina ${ }^{4}$ is a sodium ion solid ionic conductor, and an investigation of 1ts feasibility for achieving a separation of the metal from the salt was initiated. 
Inftial results of contacting single crystal sodium beta alumina with the molten ternary carbonate eutectic for two hours at $725^{\circ} \mathrm{C}$ in a gold boat showed no reaction with the melt, as determined by microscopic and ion probe studies. Continued long term, ten day tests showed no visible signs of attack by the ternary eutectic melt; however, a small weight gain indicated the possibility of some replacement of sodium ions by potassium, known to occur in nitrate melts ${ }^{5}$. Chemical analysis showed a negligible amount of lithium ion in the beta alumina, but approximately one-third of the sodium lons had been replaced by potassium ions. The results suggest that sodium beta alumina may be applicable as a sodium conductive membrane to separate molten sodium from melts for unambiguous electrochemical measurements in $\mathrm{Li}_{2} \mathrm{CO}_{3}-\mathrm{Na}_{2} \mathrm{CO}_{3}$, and possibly also in $\mathrm{K}_{2} \mathrm{CO}_{3}-\mathrm{Na}_{2} \mathrm{CO}_{3}$, if the mobility of the sodium ion is sufficiently greater than that of the potassium ion in solid sodium beta alumina.

Highly purified and well characterized sodium beta alumina powder has been obtained from Dr. P. E. D. Morgan of The Franklin Institute. Tubes to be prepared from this material will be evaluated as to their usefulness in electrochemical measurements of thermodynamic and transport properties.

\subsection{Boron Nitride (H. R. Bronstein and J. Braunstein)}

In electrochemical measurements in molten alkali-carbonates, refractory insulators stable to the carbonate melts are needed. High density alumina or lithium aluminate are the recommended container materials, but for studies of the chemical interaction of alumina or of lithium aluminate with melts, as well as for versatility of experimental design, alternative insulators would be desirable. Both thermodynamic calculations and experimental tests indicated that pyrolytic boron nitride might have limited applicability. Thermodynamic estimates were based on an assumed corrosion reaction of BN in carbonates given by

$$
2 \mathrm{BN}(\mathrm{s})+3 \mathrm{CO}_{2}(\mathrm{~g})=\mathrm{N}_{2}(\mathrm{~g})+\mathrm{B}_{2} \mathrm{O}_{3}(\mathrm{l})+3 \mathrm{CO}(\mathrm{g}) \text {. }
$$

From data in the JANAF Tables, the standard free energy change for this reaction is $-25 \mathrm{kcal}$ at $1000 \mathrm{~K}(-12 \mathrm{kcal} / \mathrm{mol} \mathrm{BN})$, and $-10 \mathrm{kcal}$ at $700 \mathrm{~K}$ $(-5 \mathrm{kcal} / \mathrm{mol} \mathrm{BN})$ indicating instability of the $\mathrm{BN}$, unless there is a 
kinetic barrier to its decomposition.

The effect of varying reducing or oxidizing conditions can be evaluated by writing the free energy as

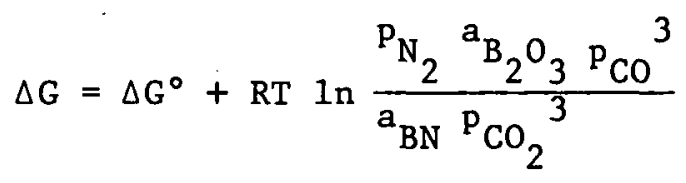

The activity of solid $\mathrm{BN}$ is unity. If an acceptable activity of the corrosion product $\mathrm{B}_{2} \mathrm{O}_{3}$ is arbitrarily set at $10^{-3}$, the expression, at . $1000 \mathrm{~K}$, becomes

$$
\begin{aligned}
& \Delta G / \text { kcal }=\Delta G^{\circ}{ }_{1000 \mathrm{~K}}+4.600 \log \left[\mathrm{P}_{\mathrm{N}_{2}}\left(\frac{\mathrm{P}_{\mathrm{CO}}}{\mathrm{P}_{\mathrm{CO}_{2}}}\right)^{3} 10^{-3}\right] \\
& \Delta G_{1000 \mathrm{~K}}=-33.6+4.6 \log \mathrm{P}_{\mathrm{N}_{2}}\left(\frac{{ }^{\mathrm{P}_{\mathrm{CO}}}}{\mathrm{P}_{\mathrm{CO}}}\right)^{3}
\end{aligned}
$$

The second term on the right can be increased by increasing $\mathrm{N}_{2}$ pressure or the $\mathrm{CO} / \mathrm{CO}_{2}$ ratio, the latter having the greater effect: At one atmosphere pressure of $\mathrm{N}_{2}$ a ratio $\mathrm{p}_{\mathrm{CO}} / \mathrm{P}_{\mathrm{CO}_{2}} \sim 1000$ would change the sign of the free energy, indicating stability unless some other corrosion reaction occurs. The calculation suggests that under sufficiently reducing conditions, BN might be stable to carbonates even in the absence of a kinetic barrier. In experimental tests at $500^{\circ} \mathrm{C}$, under a $\mathrm{CO}_{2}$ pressure slightly greater than atmospheric, pyrolytic boron nitride specimens contacted with the molten ternary eutectic ( $\mathrm{Li}-\mathrm{Na}-\mathrm{K})_{2} \mathrm{CO}_{3}$ in a gold boat for a period of 5 hours exhibited no visible signs of attack or weight change. However, specimens held at $600-700^{\circ} \mathrm{C}$ for 3 hours showed a weight loss of $5 \%$. The experimental tests indicate the possible limited compatibility of pyrolytic boron nitride with carbonate melts at temperatures below $550^{\circ} \mathrm{C}$. The calculations show that evaluation of the possible usefulness of BN would require a more detailed study of possible stabilization in controlled reducing and nitrogenous atmospheres. 


\section{TRANSPORT BEHAVIOR}

4.1 Theoretical and Model Studies * (J. Braunstein, C. E. Vallet, D. Heatherly)

In the development of more efficient batteries and fuel cells for energy storage and conversion, high temperature devices offer the possibility of lower losses from ohmic, activation and mass transport polarization, and from degradation of the thermal energy available from the primary source. Molten salts offer the capability of high temperature operation, and their mixtures provide a wide range of choices for physical and electrochemical properties of electrolytes ${ }^{6}$. Mass transport polarization in electrolytic devices such as batteries and fuel cells may arise from two kinds of concentration gradients. The first, commonly recognized kind, is that of electroactive species which may be present at low concentrations in the melt, e.g., $\mathrm{H}_{2}, \mathrm{CO}_{2}, \mathrm{O}_{2}, \mathrm{H}_{2} \mathrm{O}$ and $\mathrm{CO}$ in molten carbonates. A second, frequently overlooked, contribution may arise from concentration gradients of the major constituents as a result of migrational separation or migrational polarization of, e.g., $\mathrm{Li}^{+}$and $\mathrm{K}^{+}$in a mixture of $\mathrm{Li}_{2} \mathrm{CO}_{3}$ and $\mathrm{K}_{2} \mathrm{CO}_{3}$ in a carbonate fuel cell $7,8,9$. Although the primary effect of such concentration gradients of $\mathrm{Li}^{+}$and $\mathrm{K}^{+}$on cell voltage is probably small, the secondary effects of changes in composition at the electrode surfaces may be significant, and need to be considered in cell design and modeling.

In a fuel cell analog with a (binary) $\mathrm{Li}_{2} \mathrm{CO}_{3}-\mathrm{K}_{2} \mathrm{CO}_{3}$ electrolyte, a $\mathrm{CO}$ anode and $\mathrm{CO}_{2}, \mathrm{O}_{2}$ cathode the electrodes behave as membranes permeable to carbonate ion constituent and, relative to an electrode, the transference number of carbonate ion is $t_{C}{ }^{V}=-1$. In terms of the Hittorf transference number of $\mathrm{Li}^{+}$relative to carbonate ion $\left(t_{L}{ }^{\mathrm{C}}=1-t_{\mathrm{K}}{ }^{\mathrm{C}} ; \mathrm{t}_{\mathrm{C}}{ }^{\mathrm{C}}=0\right)$, the flux equation, derived from the thermodynamics of irreversible processce, for the fl.nw of lithium ions relative to the electrode surface is ${ }^{7}$

* The theoretical basis of the model studies applied to molten carbonate fuel cell electrolytes is part of a program "Physical Chemistry of Molten Salts in Energy Utilization," supported by the Materials Science Branch of ERDA's Division of Physical Research. 


$$
-J_{L}^{V}=D \frac{\partial C_{L}}{\partial \xi}-\left(t_{L}^{C}-X_{L}\right) I / F
$$

The boundary conditions at the electrode-electrolyte interfaces $(\xi=0 ; \xi=\Xi)$ become, since alkali ions do not cross the boundaries,

$$
\left[\mathrm{J}_{\mathrm{L}}^{\mathrm{V}}=0 ; \quad \mathrm{I}=\mathrm{F} \frac{\mathrm{D}}{\mathrm{t}_{\mathrm{L}}^{\mathrm{C}}-\mathrm{X}_{\mathrm{L}}} \quad \frac{\partial \mathrm{C}_{\mathrm{L}}}{\partial \xi}\right]_{\xi=0, \xi=\Xi}
$$

The diffusion-migration equation becomes

$$
\frac{\partial C_{T_{1}}}{\partial t}=\frac{\partial}{\partial \xi}\left[D \frac{\partial C_{L}}{\partial \xi}-\left(t_{L}{ }^{C}-X_{L}\right) \quad I / F\right]
$$

Computer simulation of composition profiles by means of a finitc difference algorithm ${ }^{8}$ has been carried out for a molten carbonate fuel cell analog using plausible estimates of the physical parameters for an order of magnitude estimate of the effect ${ }^{7,10}$. The transference number was written $t_{L}{ }^{C}=\frac{C_{L} U_{L}}{C_{L} U_{L}+C_{K} U_{K}}$ with constant but unequal alkali ion mobilities relative to carbonate. The mobility ratio of the alkali cations was taken as 2 . $\left(\mathrm{J}_{\mathrm{L}} / \mathrm{U}_{\mathrm{K}}, 2\right)$. A constant current densicy of $0.15 \mathrm{~A} / \mathrm{cm}^{2}$ was employed in the initial calculations, with an electrode ocparation of $0.2 \mathrm{ctu}$. Although some computations with variable diffusion coefficient have been carried out, the essential features are indicated with a constant $D=10^{-5} \mathrm{~cm}^{2} \mathrm{~s}^{-1}$. Figure 1 shows the depletion with lime of $\mathrm{Li}^{+}$at one electrode. A nearly symmetrical accumulation occurs at the other electrode. A significant concentration gradient develops in a short time, and a steady state is attained in about thirty to forty minutes. Since the direction of positive current flow through the cell is from the (negative) anode to the (positive) cathode, the more mobile cation $\left(\mathrm{Li}^{+}\right)$is depleted at the anode and accumulated at the cathode. (If the cell were subjected to electrolysis, the more mobile $\mathrm{Li}^{+}$would accumulate at the negative electrode and be depleted at the positive electrode.) 


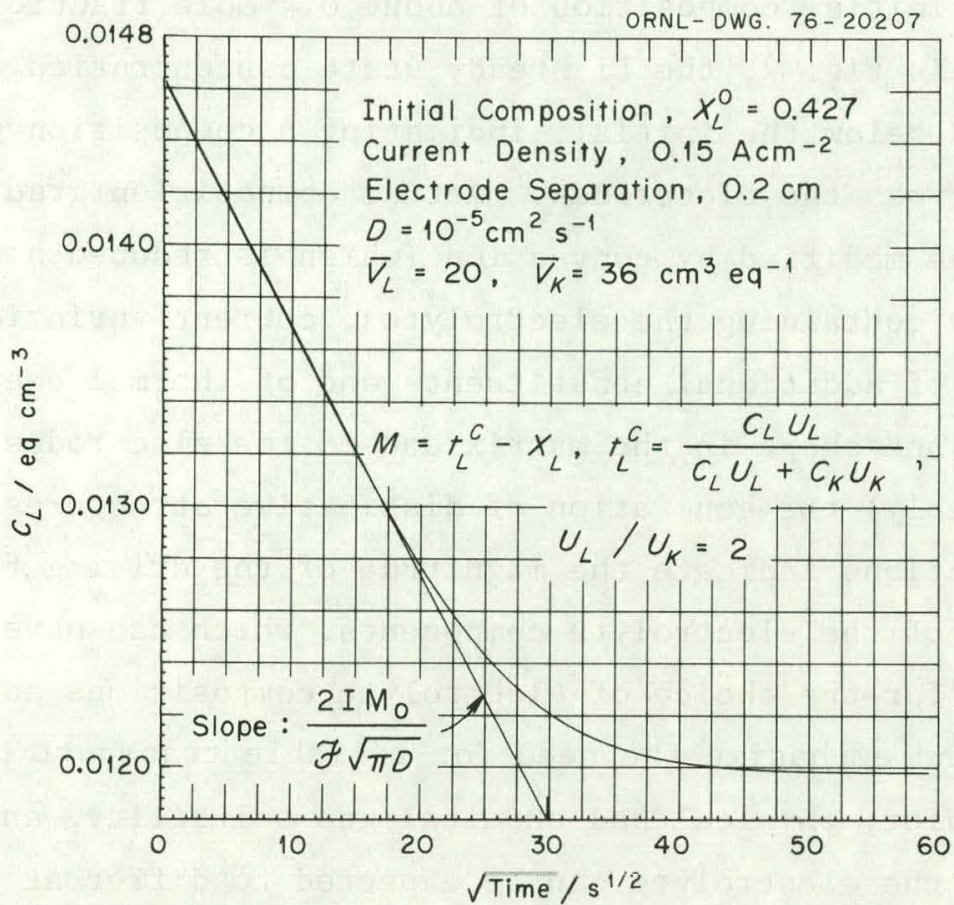

Fig. 1. Migrational contribution to concentration change at positive electrode vs. square root of time.

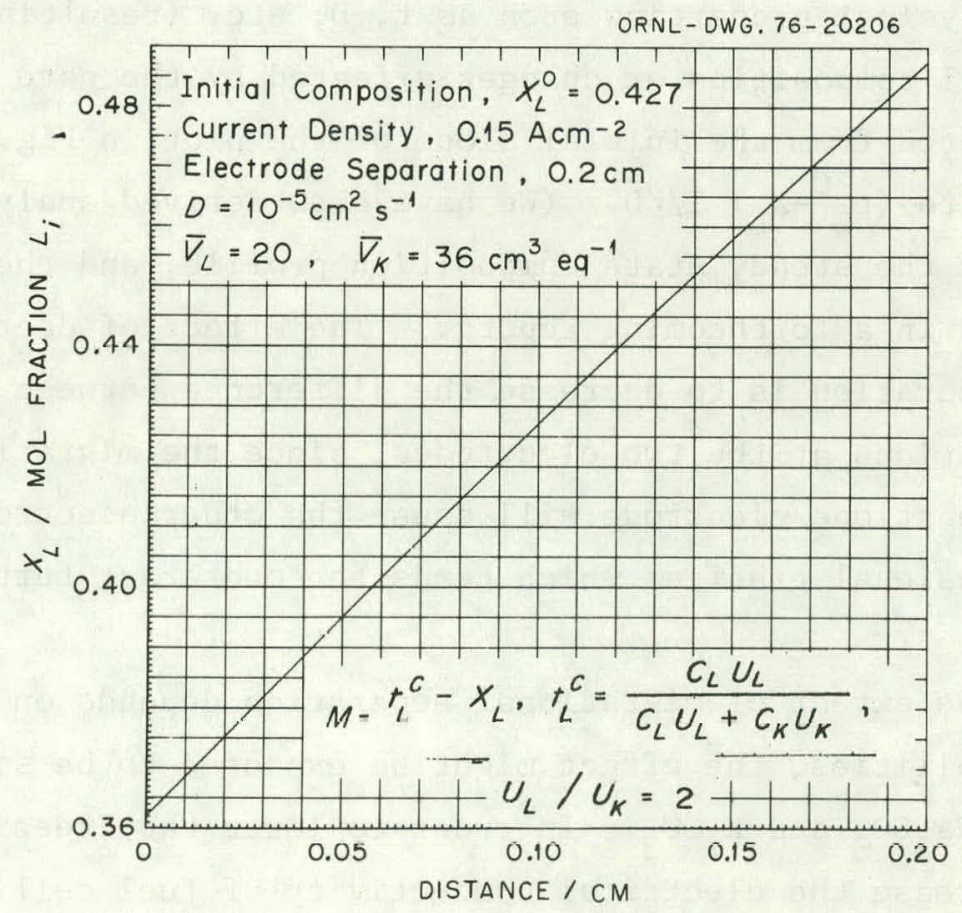

Fig. 2. Migrational contribution to steady state composition profile. 
With an initial composition of about 0.4 mole fraction $\mathrm{Li}_{2} \mathrm{CO}_{3}$, as indicated in Fig. 2, the Li steady state concentration at the anode is nearly $20 \%$ below the initial, indicating a composition gradient of nearly $40 \%$ across the electrodes. Actual composition gradients would undoubtedly be modified by convection (which is reduced however, by the porous matrix containing the electrolyte), current variations, coupling to the flows of additional constituents and of thermal energy, effects of pore size and shape in the matrix and in the electrodes, edge effects, and (conceivably) the generation of dissipative structures. Nevertheless, these computations indicate the magnitude of the driving force towards a separation of the electrolyte components, which can have important consequences for the choice of electrolyte compositions and operating conditions, and emphasize the need for reliable transport property data. Wetting behavior, physical and chemical gas solubility, and phase stability in the electrolyte can be expected to differ at the two electrodes, affecting electrolyte losses in different regions of the cell, corrosion, and the possible precipitation of unwanted solid phases. The effect of changed operating conditions (e.g., current density) or changed physical properties such as $t, D$, etc. (resulting from changes of the initial composition or changes effected by the pore structure) can be estimated from the initial slope of the plot in Fig. 1, which is proportional to $\left(t_{L}{ }^{C}-X_{L}\right) I / \sqrt{D}$. (We have also derived analytical expressions for the steady state composition profile, and the results will be summarized in a forthcoming report.) The effect of decreasing electrode separation is to decrease the difference between the steady state compositions at the two electrodes, since the migrational composition change at one electrode will cause the other electrode to see a steeper diffusional gradient which tends to counteract further migrational separation.

Since the extent of migrational separation depends on the difference of cation mobilities, the effect might be expected to be smallest in mixtures of $\mathrm{Na}_{2} \mathrm{CO}_{3}$ and $\mathrm{K}_{2} \mathrm{CO}_{3}$. In order to lower the freezing temperature and increase the electrical conductivity of fuel cell electrolytes, however, $\mathrm{Li}_{2} \mathrm{CO}_{3}-\mathrm{K}_{2} \mathrm{CO}_{3}$, $\mathrm{Li}_{2} \mathrm{CO}_{3}-\mathrm{Na}_{2} \mathrm{CO}_{3}$ or ternary alkali carbonate mixtures 
are more likely candidates so that migrational polarization may be a phenomenon that needs to be lived with and better understood.

Experimental tests of the above concepts and equations have been initiated. Apparatus for the measurement of composition profiles under the influence of current flow in alkali carbonate-lithium aluminate tiles are described in 4.2 below. Experimental tests of the validity of the migrational polarization equations are being carried out also in a simpler model system for which the transport coefficients (diffusion coefficients and transference numbers) are known, $\mathrm{KNO}_{3}-\mathrm{AgNO}_{3}$. Silica cells with silver electrodes have been constructed for electrolysis experiments with free electrolyte and with electrolyte confined in a porous matrix consisting of silica frits of differing porosity. Concentrations at the electrode surface are determined as a function of time by monitoring the emf, and the porous frits are sectioned and analyzed following electrolysis to determine the composition profile. Preliminary experiments with the free electrolyte cells show initial time dependence of the concentration at the electrode surface consistent with our computations and the known diffusion coefficient and transference number. The long time behavior and the effects of porous matrix and of electrode separation are being investigated.

\subsection{Electrolysis of $\mathrm{LiAlO}_{2}-(\mathrm{Li}, \mathrm{K}) \mathrm{CO}_{3}$ Tiles (H. R. Bronstein and}

J. Braunstein)

Among the needed transport coefficients in potential molten carbonate fuel cell electrolytes are the cation transference numbers relative to the carbonate ion. The classical methods for the measurement of transference numbers are: emf measurements of cells with and without transference; moving boundary; and the Hittorf (electrolysis) method. The first method requires electrodes reversible to a cation and an anion of the electrolyte and is not yet feasible for molten carbonate mixtures. The second requires boundary-sensing devices, which would be difficult to apply in molten carbonates. The Hittorf method is based on measurement by analysis of the net change in the quantity of an ion constituent in the vicinity of an electrode as a result of the faradaic prucess at that electrode and the migration of that in constituent 
towards (or away from) the electrode. In the application of the Hittorf method to a dilute constituent, the solution in the regions near the electrodes, where all of the composition changes take place, and in a central region undergoing no composition change are analyzed to determine the transference number in a small composition interval, and the electrode spacing is large enough to prevent diffusive mixing during the time of the electrolysis. Special consideration is needed in applying the method to the transference numbers of major constituents in a molten salt mixture. The basic equations of the Hittorf experiment are those of section 3.1, and Figs. 1 and 2 indicate several constraints in the application of a Hittorf-type method to binary molten salt mixtures: 1) The number of coulombs in the electrolysis must be large enough to permit accuracy in the small differences of composition to be measured. 2) The composition change hetween the electrode surfacc and the central region of unchanged composition must be small enough that the calculated (average) transference number is meaningful for the average concentration. 3) The electrode separation, current density, and electrolysis time must be such as to permit a central region of unchanged composition between the regions of changed composition at the electrodes. Electrolysis experiments have been initiated, both to evaluate the feasibility of the Hittorf method for transference numbers and, perhaps more important, to obtaln direct measurements of composition profiles across an electrolyzed tile.

An apparatus constructed for evaluation of a Hittorf-type measurement of transference numbers and for determination of composition profiles produced by current flow in alkali carbonate-lithium aluminate tiles is illustrated in Fig. 3. The carbonate tile ${ }^{*}, \mathrm{E}$, is a disk 74 mils thick by 1 inch in diameter with a composition of 50 weight percent of equimolar $\mathrm{Li}_{2} \mathrm{CO}_{3}-\mathrm{K}_{2} \mathrm{CO}_{3}$ and 50 weight percent lithium aluminate. The tile is compressed between the sintered nickel disk ${ }^{*}$ electrodes, $\mathrm{D}$, by means of the insulating ("Lucalox") telescoping cylinders, B, when the two stainless steel sections are bolted together. Contacting the

\footnotetext{
* Supplied by Dr. John Ackerman, Argonne National Laboratory.
} 
ORNL- DWG. 77-4955A

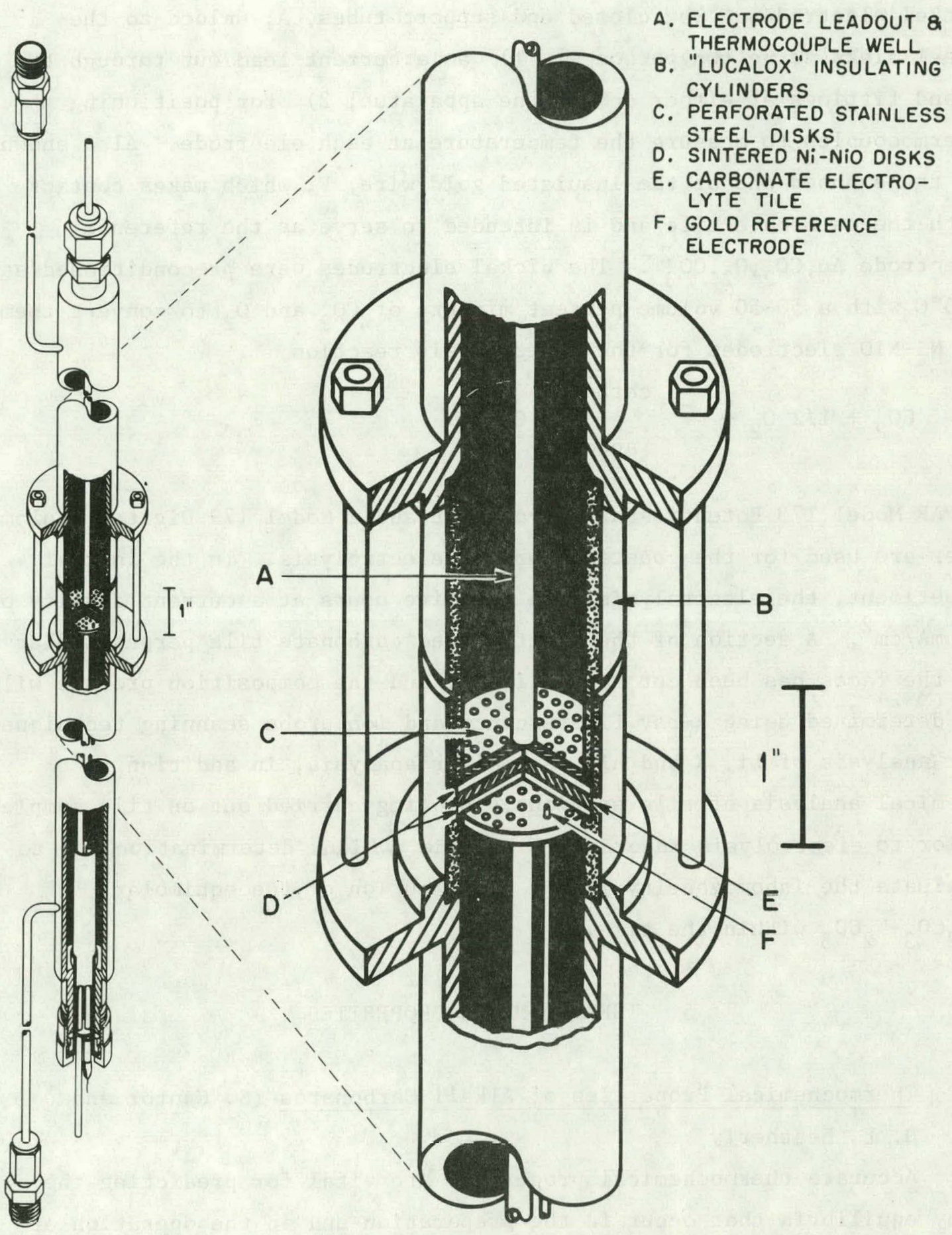

Fig. 3. Hittorf cell. 
nickel electrodes are the perforated stainless steel disks, C, of the current leads. The perforations permit gas contact with the sintered nickel electrodes. The closed end support tubes, A, welded to the steel disks serve two purposes: 1) as a current lead out through the gland fittings at either end of the apparatus; 2) for positioning thermocouples to measure the temperature at each electrode. Also shown is the exposed end of the insulated gold wire, F, which makes contact with the carbonate tile and is intended to serve as the reference electrode $\mathrm{Au}, \mathrm{CO}_{2}, \mathrm{O}_{2}, \mathrm{CO}_{3}^{2-}$. The nickel electrodes were preconditioned at $565^{\circ} \mathrm{C}$ with a $50-50$ volume percent mixture of $\mathrm{CO}_{2}$ and $\mathrm{O}_{2}$ to convert them to Ni-NiO electrodes for the electrolysis reaction

$$
\mathrm{CO}_{2}+1 / 2 \mathrm{O}_{2}+\mathrm{e}^{-} \underset{\text { anodic }}{\stackrel{\text { cathodic }}{\rightleftarrows}} \mathrm{CO}_{3}{ }^{2-} .
$$

A PAR Model 173 Potentiostat/Galvanostat and a Mode1 179 Digital Coulometer are used for the constant current electrolysis. In the initial experiment, the electrolysis time was five hours at a current density of $40 \mathrm{~mA} / \mathrm{cm}^{2}$. A section of the electrolyzed carbonate tile perpendicular to the faces has been cut and polished, and the composition profile will be determined using $x$-ray fluorescence and ion probe scanning terhniques for analysis of $\mathrm{Li}, \mathrm{K}$ and $\mathrm{Al}$. A simflar analysis, in addition to chemical analysis of tile sections, is being carried out on tile samples prior to electrolysis in order to provide a blank determination and to evaluate the inhomogeneity in the distribution of the equimolar $\mathrm{Li}_{2} \mathrm{CO}_{3}-\mathrm{K}_{2} \mathrm{CO}_{3}$ within the tile.

\section{THERMODYNAMIC PROPERTIES}

\subsection{Thermochemical Properties of Alkali Carbonates (S. Cantor and} D. E. Heatherly Accurate thermochemical properties are vital for predicting the many equilibria that occur in the preparation and in the operation of fuel cells. We have begun a critical review, starting with the electrolyte components. 
The thermochemical functions of $\mathrm{Li}_{2} \mathrm{CO}_{3}, \mathrm{Na}_{2} \mathrm{CO}_{3}$ and $\mathrm{K}_{2} \mathrm{CO}_{3}$ are compiled in the JANAF tables ${ }^{11}$, the last review of the data having been completed In March 1966. The tables for the three carbonates were examined and some errors and omissions were found:

$\underline{\mathrm{Li}}_{2} \mathrm{CO}_{3}$ : There is an error in the listing of a solid transition at $623^{\circ} \mathrm{K}$ with an estimated enthalpy of transition of $0.134 \mathrm{kcal} / \mathrm{mol}^{-1}$. This transition was attributed to Reisman ${ }^{12}$ who obtained the data, via DTA, in the absence of a $\mathrm{CO}_{2}$ atmosphere over the salt sample; In fact, Reisman assigned the result to either a solid transition in $\mathrm{Lt}_{2} \mathrm{O}$ or, more 1ikely, to a eutectic at high carbonate concentration in the system,

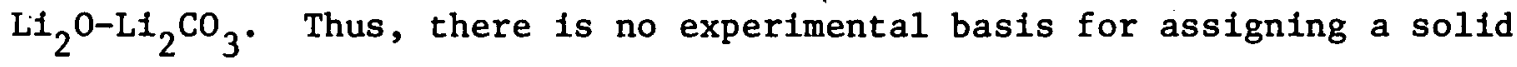
transition to $\mathrm{Li}_{2} \mathrm{CO}_{3}$ at $623^{\circ} \mathrm{K}$.

In the JANAF listing, the other solid transition, at $683^{\circ} \mathrm{K}$, is estimated to have a transition enthalpy of $0.535 \mathrm{kcal} \mathrm{mol}^{-1}$, exactly one twentieth of the listed enthalpy of fusion. This value was obtained from the relative DTA areas given in Reisman's paper. Given the qualitative nature of the original data, the value of $0.535 \mathrm{kcal} \mathrm{mol}^{-1}$ must be considered very uncertain.

$\mathrm{Na}_{2} \mathrm{CO}_{3}$ : The listed temperature of solid transition $\left(723.15^{\circ} \mathrm{K}\right.$ ) and its associated enthalpy $\left(0.165 \mathrm{kcal}^{\mathrm{mole}} \mathrm{e}^{-1}\right)$ are very questionable. In fact, it is now known from crystallographic and DTA evidence ${ }^{13}$ that $\mathrm{Na}_{2} \mathrm{CO}_{3}$ has two solid transitions, at $\sim 634^{\circ} \mathrm{K}$ and at $\sim 762^{\circ} \mathrm{K}$.

Since the last JANAF update for $\mathrm{Na}_{2} \mathrm{CO}_{3}$, new, more reliable heat capacities have been measured ${ }^{14}$ in the range, $15-300^{\circ} \mathrm{K}$. When the new value for $\varepsilon_{298}^{\circ}\left(=32.26 \mathrm{cal} \mathrm{mol}^{-1} \mathrm{deg}^{-1}\right)$ is applied, the standard entropy of formation and free energy of formation at $298.15^{\circ} \mathrm{K}$, now change to $-67.19 \mathrm{cal} \mathrm{mol}^{-1} \mathrm{deg}^{-1}$ and $-250.23 \mathrm{kcal}^{-1} \mathrm{~mol}^{-1}$.

$\underline{\mathrm{K}}_{2} \underline{\mathrm{CO}}_{3}$ : As for the other two alkaline carbonates, there is question about solid transitions. JANAF does not note a solid transition, even though Reisman had reported one at $695^{\circ} \mathrm{K}$.

It seems clear that some. JANAF-listed properties (especially enthalpy of transition and heat capacities) of the crystalline alkali carbonates are incorrect. These errors increase the uncertainties in the formation thermochemistry of these compounds. Apparently, B. K. Anderson ${ }^{15}$, 
Technica1 University of Denmark, has also noted uncertainties in the JANAF data.

Finally, the formation thermochemistry given in the JANAF tables are shown as Table $I$. This is noted here because a similar table given by Maru et al., p. 86, contains some rather large errors.

Table I. STANDARD ENTROPY, ENTHALPY AND FREE ENERGY OF FORMATION AT 298.15K BASED ON JANAF TABLES

\begin{tabular}{|c|c|c|c|c|c|c|}
\hline & cal $\mathrm{mol}^{-1} \mathrm{deg}^{-1}$ & $\mathrm{~J} \mathrm{~mol}^{-1} \mathrm{deg}^{-1}$ & kcal mol ${ }^{-1}$ & $\mathrm{~kJ} \operatorname{mol}^{-1}$ & kcal $\mathrm{mn}^{-1}$ & $k, J \operatorname{mol} 1^{-1}$ \\
\hline $\mathrm{LI}_{2} \mathrm{CO}_{3}$ & -67.216 & -281 & $=290.64$ & -1216 & -270.6 & -1132 \\
\hline $\mathrm{Na}_{2} \mathrm{CO}_{3}$ & -66.281 & $\rightarrow \quad-277$ & -270.26 & -1131 & -250.5 & -1048 \\
\hline $\mathrm{K}_{2} \mathrm{CO}_{3}$ & -68.603 & -287 & -274.9 & -1150 & -254.4 & -1064 \\
\hline
\end{tabular}

DSC Measurements: The foregoing indicated a real need for improvement in the thermochemical data of the alkali carbonates. Accordingly, we have inftiated a calorimetric study of $\mathrm{Li}_{2} \mathrm{CO}_{3}, \mathrm{Na}_{2} \mathrm{CO}_{3}$, and $\mathrm{K}_{2} \mathrm{CO}_{3}$, using a Perkin-Elmer (DSC-2) Differential Scanning Calorimeter. Thio instrument is ideally suited for determining enthalpies of transition and changes of heat-capacity that occur in the range, $-65^{\circ}$ to $727^{\circ} \mathrm{C}$.

Preliminary measurements have been carried out on 5-10 mg samples of the carbonates sealed in standard DSC gnid containers. The samplea had been drled by passing $\mathrm{CO}_{2}$ for 18 hours at $425^{\circ} \mathrm{C}$ over analytical-or reagent-grade materials contained in a shallow gold vessel; this treatment presumably converted trace oxide and hydroxide into carbonate. To prevent contamination by moisture, all sample transfer and sealing operations were carried out in a helium-filled glovebox.

The results obtained thus far are presented in the following table: 
DSC MEASUREMENTS IN CRYSTALLINE $\mathrm{Li}_{2} \mathrm{CO}_{3}, \mathrm{Na}_{2} \mathrm{CO}_{3}, \mathrm{~K}_{2} \mathrm{CO}_{3}$

Transition Type of

Temp. Transition

Interpretation of DSC Thermograms

$\mathrm{Li}_{2} \mathrm{CO}_{3} \quad 410^{\circ} \mathrm{C} \quad$ First-order $\quad \Delta \mathrm{H}=200 \pm 20 \mathrm{cal} \mathrm{mol}^{-1}$

$\mathrm{Na}_{2} \mathrm{CO}_{3} \quad 357-360^{\circ} \mathrm{C} \quad$ Second-order slight upsweep in $\mathrm{C}_{\mathrm{p}}$ with temp., then $C_{p}$ decreases $\sim 6 \mathrm{cal} \mathrm{mol}^{-1} \mathrm{deg}^{-1}$

$484-488^{\circ} \mathrm{C} \quad$ Second-order Roughly the same, except $C_{p}$ decreases $\sim 9 \mathrm{cal} \mathrm{mol}^{-1} \mathrm{deg}^{-1}$.

$\mathrm{K}_{2}\left(\mathrm{O}_{3} \quad 420-422^{\circ} \mathrm{C} \quad\right.$ Second-order Same features as for $\mathrm{Na}_{2} \mathrm{CO}_{3}$;

$C_{\mathrm{p}}$ decreases $\sim 13 \mathrm{cal} \mathrm{mol}^{-1} \mathrm{deg}^{-1}$

All samples were studied in the full temperature range, $-65^{\circ}-727^{\circ} \mathrm{C}$. Only $\mathrm{Li}_{2} \mathrm{CO}_{3}$ showed first order transitions: at $410^{\circ} \mathrm{C}$ and at $\sim 725^{\circ} \mathrm{C}$, the melting point. (The instrument is presently being used to obtain the heat of fusion of $\mathrm{Li}_{2} \mathrm{CO}_{3}$ ) The transition temperature observed for $\mathrm{Na}_{2} \mathrm{CO}_{3}$ and for $\mathrm{K}_{2} \mathrm{CO}_{3}$ has been previously noted ${ }^{13}$ but the type of transition has not been clear. It is expected that better resolution of transition energetics in $\mathrm{Na}_{2} \mathrm{CO}_{3}$ and $\mathrm{K}_{2} \mathrm{CO}_{3}$ will be obtained when we measure heat capacities.

In the near future, DSC measurement of carbonates and other fuel cell materials w11l continue. We plan to study the following:

a) enthalpy of fusion of $\mathrm{Li}_{2} \mathrm{CO}_{3}$ and of $\mathrm{LiKCO}_{3}$

b) enthalpy of transition of $\mathrm{LiAlO}_{2}$

c) heat capacities of crystalline $\mathrm{Li}_{2} \mathrm{CO}_{3}, \mathrm{Na}_{2} \mathrm{CO}_{3}$, and $\mathrm{K}_{2} \mathrm{CO}_{3}$.

\subsection{Free Energies of Molten Carbonate Mixtures}

\subsubsection{Electrochemical Measurements (H. R. Bronstein)}

With the demonstrated compatibility of sodium beta alumina to alkali carbonate melts, thermodynamic measurements can now be made on $\mathrm{Na}_{2} \mathrm{CO}_{3}$ containing melts by emf measurements of the formation cell: 


$$
\begin{aligned}
& \mathrm{Na} \text { /sodium beta alumina } \mid \begin{array}{c|c}
\mathrm{Na}_{2} \mathrm{CO}_{3}(\mathrm{X}) & \mathrm{Au} \\
\mathrm{Li}_{2} \mathrm{CO}_{3}(1-\mathrm{X}) & \mathrm{CO}_{2} \\
(\text { liquid }) & \mathrm{O}_{2}
\end{array} \\
& 2 \mathrm{Na} \text { (liq) }+1 / 2 \mathrm{O}_{2}+\mathrm{CO}_{2} \rightarrow \mathrm{Na}_{2} \mathrm{CO}_{3 \text { (melt) }} \\
& \Delta \mathrm{G}=\Delta \mathrm{G}^{\circ}+\mathrm{RT} \ln \frac{\mathrm{a} \mathrm{a}_{2} \mathrm{CO}_{3}}{\mathrm{P}_{\mathrm{CO}_{2}} \mathrm{P}_{2} \mathrm{O}_{2}}
\end{aligned}
$$

The cell can be employed to obtain lle composition dependenre nf activity coefficients in $\mathrm{Na}_{2} \mathrm{CO}_{3}$-containing melts. Furthermore, the free energy of formation of $\mathrm{Na}_{2} \mathrm{CO}_{3}$ in the precipitating solid phase (pure $\mathrm{Na}_{2} \mathrm{CO}_{3}$ or solid solution) can be obtained at various temperatures by slightly exceeding the soluhtlity limit in the varlous carbonate melts.

An apparatus is now being fabricated for performing the above emf experiment. A Hasting Gas Blending System has been obtained for accurately controlling the $\mathrm{CO}_{2}-\mathrm{O}_{2}$ ratios and both the incoming and outgoing gas stream from the carbonate electrode will be analyzed with a Carle Analytical Gas Chromatograph Model $111 \mathrm{H}$.

\subsubsection{Activity Coefficients from Phase Di,agrams (s. Cantor)}

A review of the phase diagrams of the alkaline carbonates is being rarried out: a) Lu provide estimates for comparison with activity coefficients to be derived from upcoming emf measurements (by H. R. Bronstein), h) to determine wheller or not the activity coefficients fit simple models of solution, and $c$ ) to uncover uncertainties in the phase diagrams themselves or in the thermodynamic data (heats of fuston and heat capacities) through which activity coefficients are computed from liquidus temperatures.

Activity coefficients obtained from the phase diagrams of the systems, $\mathrm{Li}_{2} \mathrm{CO}_{3}-\mathrm{Na}_{2} \mathrm{CO}_{3}$ and $\mathrm{Li}_{2} \mathrm{CO}_{3}-\mathrm{K}_{2} \mathrm{CO}_{3}$, are 1isted in Table. II. Deviations from ideality are greater in $\mathrm{Li}_{2} \mathrm{CO}_{3}-\mathrm{K}_{2} \mathrm{CO}_{3}$ than in $\mathrm{Li}_{2} \mathrm{CO}_{3}-$ $\mathrm{Na}_{2} \mathrm{CO}_{3}$. Excess partial molar free energies of mixing, calculated from 
these activity coefficients, tend to be roughly $0.5 \mathrm{kcal} / \mathrm{mol}$ more negative than the corresponding partial molar heats of mixing, the latter obtained from Andersen and Kleppa ${ }^{16}$. Thus, these binary molten mixtures are definitely not regular solutions. In fact, for $\mathrm{Li}_{2} \mathrm{CO}_{3}-$ $\mathrm{Na}_{2} \mathrm{CO}_{3}$ the magnitude of the $\mathrm{T} \Delta \overline{\mathrm{S}}^{\mathrm{xS}}$ term is greater (i.e., more negative) than the corresponding partial molar heat of mixing.

Finally, it should be remembered that in calculating the activity coefficients (and excess free energies), we assumed that, at the liquidus temperature, a pure alkaline carbonate, not a solid solution, precipitates from the melt. For the $\mathrm{Li}_{2} \mathrm{CO}_{3}-\mathrm{rich}$ side of the phase diagrams, this is, in all probability, a valid assumption. However, for the $\mathrm{Na}_{2} \mathrm{CO}_{3}-\mathrm{rich}$ side (of the $\mathrm{Li}_{2} \mathrm{CO}_{3}-\mathrm{Na}_{2} \mathrm{CO}_{3}$ system), it is not difficult to imagine the smaller $\mathrm{Li}^{+}$ion fitting into a cation lattice site. Although there is presently no evidence for solid solubility of $\mathrm{Li}_{2} \mathrm{CO}_{3}$ in $\mathrm{Na}_{2} \mathrm{CO}_{3}$, the activity coefficients of $\mathrm{Na}_{2} \mathrm{CO}_{3}$ presented in Table II should, nevertheless, be used with some caution. 
Table II

ACTIVITY COEFHLCLENTS ${ }^{3}$ IN $\mathrm{Li}_{2} \mathrm{CO}_{3}-\mathrm{Na}_{2} \mathrm{CO}_{3}$ AND

$\mathrm{Li}_{2} \mathrm{CO}_{3}-\mathrm{K}_{2} \mathrm{CO}_{3}$ DERIVED FROM LIQUIDUS TEMPERATURES ${ }^{\mathrm{b}}$

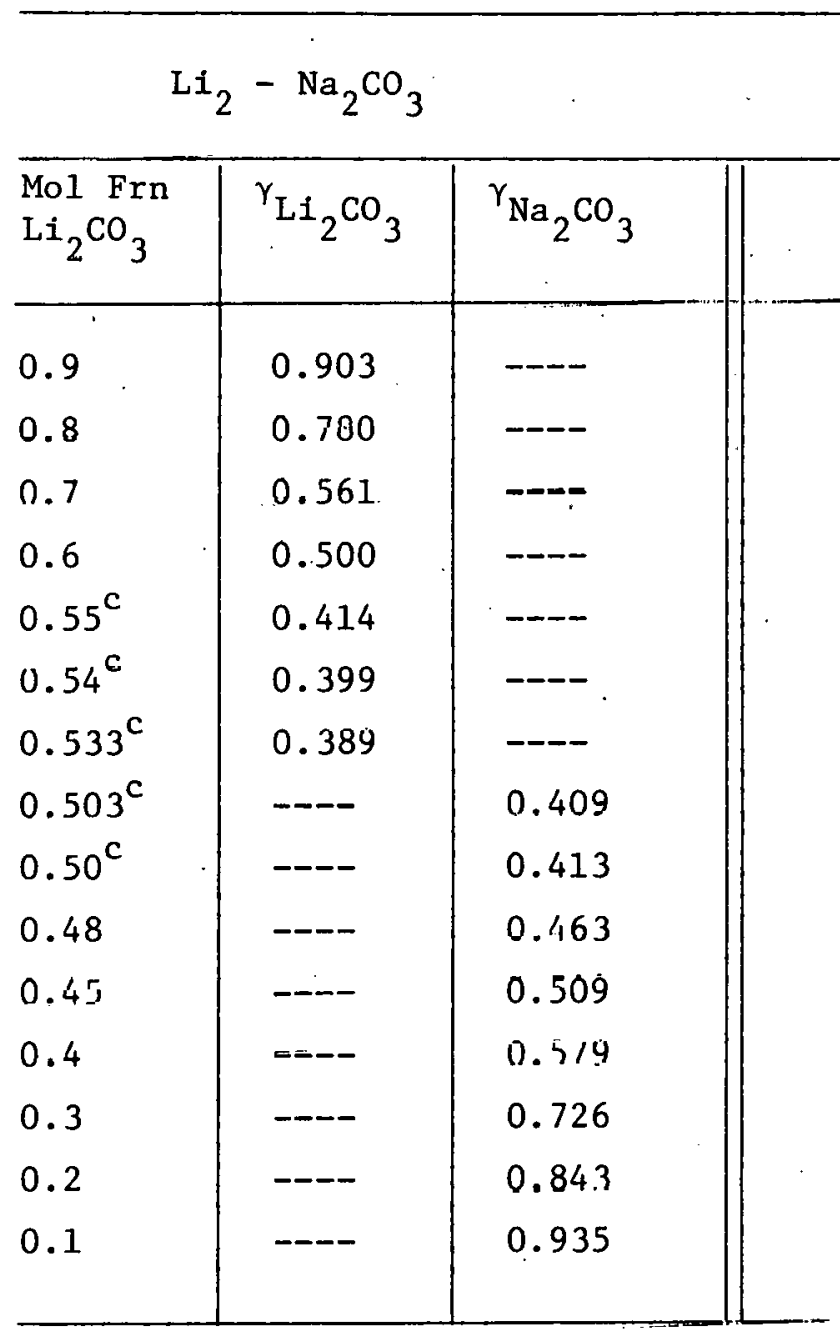

$\mathrm{Li}_{2} \mathrm{CO}_{3}-\mathrm{K}_{2} \mathrm{CO}_{3}$

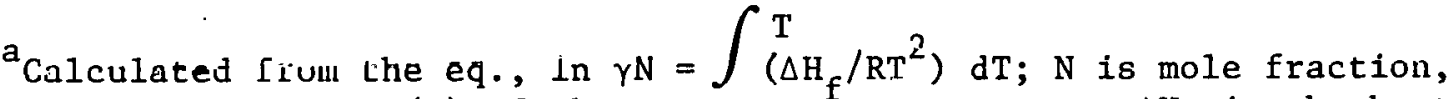
$T_{M}$ is the melting temp. (K) of the $T_{M}$ pure component, $\Delta H_{f}$ is the heat of fusion; heat of fusion and heat capacity taken from $G$. J. Janz et al., Trans. Farad. Soc. 59, 841 (1963).

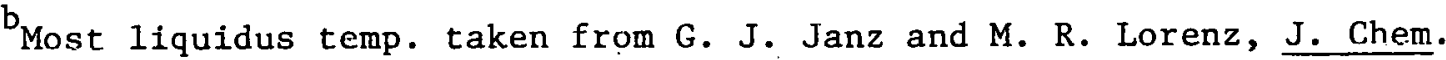
Eng. Data $\underline{6}, 321$ (1961).

Ciquidus temp. from E. J. Cairns and D. I. MacDonald, Nature 194,441 , May 5, 1962. 


\section{REFERENCES}

1. S. H. Nelson and J. P. Ackerman, Fuel Cell Benefit Analysis, Argonne National Laboratory Report, ANL/ES-51, June 1976.

2. H. C. Maru, A. Pigeaud, E. Ong, J. R. Selman, V. Sampath, L. G. Marianowski, and K. F. Blurton, Fuel Cell Research on Second-Generation Molten Carbonate Systems, Vol. II, Characteristics of Carbonate Melts, Project 8984, Quarterly Progress Report, July 1September 30, 1976, Institute of Gas Technology, Chicago.

3. J. Braunstein and H. Braunstein, "EMF Measurements in Molten Salts," Ch. 18 in Experimental Thermodynomics, V. II, eds. B. LeNeindre and B. Vodar, Butterworths, London, 1975, see pp. 912-915.

4. J. McGechin and A. Hooper, J. Materials Sci. 12, 1 (1977).

5. Y. Yao and J. T. Kummer, J. Inorg. Nucl. Chem. 29, 2453 (1967).

6. D. A. J. Swinkels, "Molten Salt Batteries and Fuel Cells, Ch. 4, pp. 165-223, Advances in Molten Salt Chemistry, Vo1. 1, eds.

J. Braunstein, G. Mamantov, and G. P. Smith, Plenum Publishing Co., New York (1971).

7. J. Braunstein and C. E. Vallet, "Migrational Polarization in High Current Density Molten Salt Electrochemical Devices," Symposium on Electrode Materials and Processes in Energy Conversion, The Electrochemical Soclety, Philadelphia, PA, May 1977, Paper No. 379.

8. C. E. Vallet and J. Braunstein, J. Electrochem. Soc. 124, 78 (1977).

9. C. E. Vallet, H. R. Bronstein, and J. Braunstein, J. EZectrochem. Soc. 121, 1429 (1974).

10. C. E. Vallet and J. Braunstein "Solution of Electrochemical Flux Equations with Variable Diffusion Coefficient and Transference Number," Symposium on Reaction Mechanisms Models and Computers, The American Chemical Society, New Orleans, March 20-25, 1977, Paper No. 186.

11. D. R. Stu1l and H. Prophet, JANAF Thermoehcmical Tah.les, 2nd Edition, NSRDS-NBS37, U. S. Dept. of Commerce, Washington, DC (1971).

12. A. Reisman, J. Am. Chem. Soc. 80 , 3558 (1958). 
13. C. N. R. Rao et al., "Crystal Structure Transformations in Inorganic Nitrites, Nitrates, and Carbonates, NSRDS-NRS 53, U. S. Dept. u[ Commerce, Washington, DC (1975).

14. C. G. Waterfield et al., Trans. Farad. Soc. 64,868 (1968).

15. Ref. 2, p. 86 .

16. B. K. Andersen and O. J. Kleppa, to be published in Acta. Chem. Scand. Data cited in Ref. 2, pp. 89-91. 


\author{
ORNL/TM-5886 \\ Dist. Cat egory UC-4
}

\title{
DISTRIBUTION LIST
}

\section{Internal}

1-2. Central Research Library

3. ORNL Patent office

4. ORNL Y-12 Technical Library, Document Reference Department

5. Laboratory Records, ORNL, RC

6-7. Laboratory Records Department

8. S. E. Beal1

9-20. J. Braunstein

21. H. R. Bronstein

22. S. Cantor

23. G. G. Fee

24. D. E. Ferguson

25. L. M. Ferris

26. W. R. Grimes

27. D. E. Heatherly

28. 0. L. Keller

29. J. P. Nichols

30. M. W. Rosenthal

31. W. D. Shults

32. A. Solomon

33. I. L. Thomas

34. C. E. Vallet

35. J. R. Weir, Jr.

36. M. K. Wilkinson

37. A. Zucker

\section{Externa1}

38. Dr. Bernard S. Baker, Energy Research Corp., 3 Great Pasture Road, Danbury, CT 06810.

39. Dr. Theodore R. Beck, Electrochemical. Technology Corp., 3935 Leary Way, NW, Seattle, WA 98107.

40. Dr. Keith Blurton, Institute of Gas Technology, 3424 S. State St., Chicago, IL 50616.

41. Dr. Alina Borucka, Borucka Research Co., 60 Chestnut St., Livingston, NJ 07039.

42. Dr. Deb Chatterji, General Electric Co., PO Box 8, Bldg. K-1, Sr.henectady, NY 12301.

43. Mr. George Ciprios, Exxon Research and Engineering Co., PO Box 8, Linden, NJ 07036.

44. R. P. Epple, Material Sciences Program, Division of Physical Research, USERDA, Washington, DC 20545.

45. Mr. Arnold P. Fickett, Electric Power Research Institute, 3412 Hillview Ave., PO Box 10412, Palo Alto, CA 94303. 
46. I. L. Harry, USERDA, Washington, DC 20545.

47. Dr. J. Huff, U. S. Army Mobility Fquipment Research and Develuptuent lenter, Electrotechnology Branch, Ft. Belvoir, VA 22060.

48. G. J. Janz, Rensselaer Polytechnic Institute, Cogswell Laboratory, Troy, NY 12181 .

49. Mr. J. M. King, Power Systems Division, United Technology Corp., PO Box 109, South Windsor, CT 06074.

50. A. R. Landgrebe, Division of Conservation Research and Technology, USERDA, Washington, DC 20545.

51. Dr. Lloyd R. Lawrence, Chief, Fuel Cells Branch, ERDA Headquarters, 20 Massachusetts Ave., Washington, DC 20545.

52. L. G. Marianowski, Institule of Gas Technology, 3424 South State St., Chicago, IL 60538.

53. L. L. Radcliffe, USERDA, ORO,

54. Dr. J. J. Rasmussen, Montana Energy and MHD Research Institute, PO Box 3809, Butte, MT 59701.

55. Dr. R. Knberts, The Mitre Corp., Westgate Research Park, McLean, VA 22101.

56. J. R. Selman, Illinois Institute of Technology, IIT Center, Chicago, IL 60616.

57. Mr. Kichard Sperburg, ERDA San Francisco Operations Office, 1333 Broadway, Wells Fargo Building, Oakland, CA 94612.

58. Prof. Ernest Yeager, Case Western Reserve University, University Circle, Cleveland, OH 44106.

59. Director of Research and Technical Support Division, ERDA, ORO. 60-260. Given Distribution as shown in TID 4500, UC-4 Chemistry. 